\title{
EXPERIMENTAL AND NUMERICAL STUDY OF PALM OILAND CASTOR OIL BIODIESEL DROPLET EVAPORATION
}

\author{
ESTUDIO EXPERIMENTAL Y NUMÉRICO DE LA EVAPORACIÓN \\ DE GOTAS DE BIODIESEL DE ACEITE DE PALMA Y ACEITE DE RICINO
}

\author{
ESTUDO EXPERIMENTAL E NUMÉRICO DA EVAPORAÇÃO DE GOTAS \\ DE BIODIESEL DE ÓLEO DE PALMA E ÓLEO E RICINO
}

\author{
M.L Botero ${ }^{1}$, A. Molina ${ }^{1 *}$ \\ ' Facultad de Minas, Universidad Nacional de Colombia - Sede Medellín \\ e-mail: amolinao@unal.edu.co
}

(Received: Nov 05, 2015; Accepted: Feb 08, 2017)

\begin{abstract}
The vaporization characteristics of Palm and Castor oil biodiesel (Ricinus comunis) droplets were studied. An experimental set-up for measuring the evaporation rate of fuel droplets at atmospheric pressure and variable temperatures was developed. The droplets were suspended on a quartz fiber with initial droplet diameters ranging from $0.9 \mathrm{~mm}$ to $1.3 \mathrm{~mm}$. The $\mathrm{D}^{2}$ law model for droplet evaporation was used to predict the evaporation rate of the fuels. Biodiesel physical properties were estimated using group contribution methods and empirical mixing rules. Numerical results accurately predict the evaporation rate of biodiesel when compared to experimental results, with maximum deviations of the evaporation of $15.2 \%$. Results show that Castor oil biodiesel evaporation rate is $48 \%$ lower than that for Palm oil biodiesel at the studied temperatures. This is explained by its higher density and vaporization enthalpy, which can be traced back to the structure of the fuel components.
\end{abstract}

Keywords: Biodiesel, Droplet Evaporation, D² Law, Evaporation Rate

How to cite: Botero, M.L., Molina, A., (2017) Experimental and Numerical Study of Palm Oil and Castor Oil Biodiesel Droplet Evaporation. CT\&F - Ciencia, Tecnología y Futuro, 6(5), 83-94.

*To whom correspondence should be sent 


\title{
RESUMEN
}

N e estudiaron las características de evaporación de gotas de biodiesel de aceite de Palma y Ricino (Ricinus comunis) en un montaje experimental que opera a presión atmosférica y diferentes temperaturas. La gota se suspende en una fibra de cuarzo con diámetros de gota iniciales entre $0.9 \mathrm{~mm}$ y $1.3 \mathrm{~mm}$. La ley $\mathrm{D}^{2}$ se utilizó para predecir las velocidades de evaporación de los combustibles. Las propiedades físicas de los dos biodiesel se estimaron mediante el método de contribución de grupos y reglas empíricas para mezclas. Los resultados de la simulación predicen adecuadamente la velocidad de evaporación de biodiesel al comparar con resultados experimentales con una desviación máxima de la velocidad de evaporación de 15.2\%. El Biodiesel de ricino presenta una velocidad de evaporación 48\% menor que el biodiesel de Palma. Esto se debe a su mayor densidad y entalpia de vaporización, que se explica por las diferencias en la estructura química de los compuestos presentes en cada combustible.

Palabras clave: Biodiesel, Evaporación de gotas, Ley D2, Velocidad de Evaporación

\section{RESUMO}

\begin{abstract}
s características de evaporação de gotas de biodiesel de óleo de Palma e Ricino (Ricinus comunis) foram estudadas em uma montagem experimental operando sob pressão atmosférica e diversas temperaturas. A gota fica suspensa em uma fibra de quartzo com diâmetros de gota iniciais entre $0.9 \mathrm{~mm}$ e $1.3 \mathrm{~mm}$. A lei D² utilizou-se para predizer as velocidades de evaporação dos combustíveis. As propriedades físicas do biodiesel foram calculadas através do método de contribuição de grupos e regras empíricas para misturas. Os resultados da simulação predizem adequadamente a velocidade de evaporação de biodiesel comparada com resultados experimentais com um desvio máximo da taxa de evaporação de 15,2\%. O biodiesel de rícino apresenta uma velocidade de evaporação $48 \%$ menor do que o biodiesel de óleo de Palma. Isto é devido a sua maior densidade e entalpia de vaporização, que se explica pelas diferenças na estrutura química dos compostos presentes em cada combustível.
\end{abstract}

Palavras-chave: Biodiesel, Evaporação de Gotas, Lei D², Velocidade de Evaporação 


\section{INTRODUCTION}

Increasing energy consumption, depletion of fossil fuels and concerns over their environmental impact has increased the utilization of alternative biodegradable non-toxic sources of energy such as biodiesel (Knother, G., Krahl, J., \& Van Gerpen, J., 2010). In fact, the global market of biodiesel has experienced a rapid growth in the recent years (Allied 2014, OECD-FAO 2016).

Most biodiesel properties are comparable with those of diesel, thus it can be used pure or blended without making considerable adjustments to the engine. It is considered that the performance of diesel-engines does not significantly change with the substitution of a certain percentage of diesel for biodiesel, however it is expected that some differences in their properties alter the performance of the engine (Murugesan, A., Umarani, C., Subramanian, R. \& N. Nedunchezhian, 2009). Small changes in composition and physical and chemical properties of the fuel can affect the jet characteristics, its evaporation and subsequent combustion, which can noticeably influence the production of pollutants such as soot and nitrogen oxides and also the engine efficiency (Basha, Gopal, \& Jebaraj, 2009; Demirbas, 2007; Rakopoulos, C. D., 2006). The combustion of liquid fuel jets is an application where droplet vaporization can be critical, because it can be the slowest process, controlling the overall combustion rate (Sirignano, 1983).

When a drop evaporates in a heated environment, heat and mass transfer occur simultaneously. The most important fuel property when determining the burning rate is the vapour heat content at the boiling point (Godsave, 1953). Differences in properties such as the latent heat of vaporization can modify the evaporation characteristics and therefore the fuel combustion process.

The fuel droplet and spray evaporation process have been under study for decades given its importance in the understanding of the spray combustion process in non-premixed engines. Several studies have been carried out experimentally, at normal gravity as well as micro-gravity (Castanet et al. 2002; Maqua, Castanet, \& Lemoine, 2008; Maqua, C., Castanet, G. \& Lemoine, F., 2008; Nomura et al., 1996), along with modelling and numerical simulations (Kryukov, Levashov, and Sazhin, 2004; Sazhin et al., 2004; Sazhin, S. S., Kristyadi, T., Abdelghaffar, W. A. \& Heikal, M. R., 2006).

In the last few years, research involving the evaporation of fuel droplets in the range of commercial fuels had increased. Numerical and experimental studies have tried to capture the evaporation characteristics of gasoline and diesel as well as some of their components (Kryukov, Levashov, and Sazhin, 2004; Sazhin, S. S., Elwardany, A. E., Sazhina, E. M. \& Heikal, M. R., 2011; Sazhin et al., 2014; Elwardany and Sazhin, 2012; Kristyadi et al., 2010). Also, due to the increasing use of renewable fuels blended with commercial fuels, ethanol (Hallett and Beauchamp-Kiss, 2010) and biodiesel (Botero, M. L., Huang, Y., Zhu, D. L., Molina, A. \& Law, C. K., 2012) have been the focus of research in the subject.

A few studies of biodiesel fuels and their blends with diesel are now available. Biodiesel fuel produced from different feedstock such as cottonseed, rapeseed, sunflower and Palm Oil have been tested as well as their mixtures with diesel (Daho et al. 2012a, 2012b; Hashimoto et al., 2015; Dirbude, Eswaran, and Kushari, 2012). When predicting the evaporation characteristics such as the evaporation rate or the droplet history, the properties of the fuels (renewable or fossil) are calculated assuming a single component or lumping all the components to a few representative ones. For diesel and gasoline that are mixtures of hundreds of hydrocarbons this is very convenient. Biodiesel is usually composed of a few mono-alkyl esters in a proportion that depends on the raw material used in the fat transesterification process. In this case, and given the lack of knowledge about these biofuels, it is very useful to be able to predict the evaporation characteristics taking into account the variations in the composition of biodiesel (Al Qubeissi, M., Sazhin, S. S., Crua, C., Turner, J. \& Heikal, M. R., 2015), which results in changes in the physical properties of the mixture. A very simple model based on the $\mathrm{D}^{2}$ law model (Law C.K, 2006) for droplet evaporation that captures the influence of the fuel mixture components in the evaporation rates was presented by the authors in the past, Botero \& Molina (2010). A subroutine for the prediction of physical properties of multicomponent fuels enabled to test any fuel or biofuel mixture in terms of the evaporation rate. 
In the present investigation the evaporation rate of Palm Oil and Castor oil biodiesel was studied numerically and experimentally. A widely used method consisting on a fiber-suspended droplet was used to characterize the evaporation of biodiesel. n-heptane was studied and compared to previous experiments (Nomura, H., Yasushige U., Hans J. R., Jun'ich S. \& Michikata K., 1996), to test the suitability of the experimental set-up. Experimental results of Palm Oil and Castor Oil biodiesel were compared to numerical simulations.

\section{EXPERIMENTAL DEVELOPMENT}

In order to characterize the evaporation of biodiesel droplets, an experimental device that enables recording the droplet diameter during the evaporation process at different ambient temperatures was designed and built. Figure 1 shows the schematic of the experimental setup. The experiment involves the evaporation of a single droplet in a stainless steel chamber of $100 \mathrm{~mm}$ diameter. Two quartz windows on the sides of the chamber allow the observation of the droplet during the evaporation process.

The droplet is supported in a quartz fiber of $250 \mu \mathrm{m}$ with an approximately $650 \mu \mathrm{m}$-diameter sphere in the bottom tip. The liquid fuel is manually injected using a $10 \mu 1$ micro-syringe, as represented in a closer view in Figure 1. Following this procedure initial droplet sizes between $1 \mathrm{~mm}$ to $1.3 \mathrm{~mm}$ are obtained. The injection of the droplet can take 2 to 3 seconds before it is completely suspended and stable. To guarantee an inert atmosphere and minimal convection, $\mathrm{N}_{2}$ is supplied at the bottom of the chamber at a rate of $500 \mathrm{sccm}$ (standard cubic centimeter per minute): standard conditions were defined as $298.15 \mathrm{~K}$ and $85.33 \mathrm{kPa}$. Under the conditions and temperatures used in the experiments the estimated Nusselt number is below unity (between 0.5-0.64), hence heat transfer due to convection can be neglected. Temperature is increased through an aluminum-kanthal coil at the bottom of the piece, and controlled using a 600 ampere variac (electrical transformer). The maximum temperature that could be achieved was $730 \mathrm{~K}$. A K-type thermocouple measured the temperature in the proximity of the droplet (approximately $4 \mathrm{~mm}$ ). The droplet was illuminated through one of the windows in order to gain clarity in the images. Through the other window a high- definition video camera recorded the droplet diameter history at 25 frames per second (fps) with a resolution of $1280 \times 720$ pixels. The video camera data was transferred into a computer as image (MPEG) files.

The images were processed using an in-house developed code implemented in MATLAB ${ }^{\circledR}$. Each video frame is separated and the droplet diameter is measured as shown in the second column of Figure 2. Because of the good contrast in the images, the code was able to exactly map the droplet and background boundaries, giving an exact mapping of the droplet. At least three different videos were analysed for each studied temperature, the results presented in this manuscript correspond to the average value and the standard deviation (error bars in the plots) represents the repeatability of the measurements. The fuels tested were n-heptane (99,15\% purity), Palm Oil biodiesel (POB) and Castor Oil biodiesel (COB). The biofuels were provided by the Crude Oils and Derivatives laboratory of Universidad Nacional de Colombia, Sede Medellín (Colombia), and characterised as per (Benjumea, P., Agudelo, J. \& Agudelo, A., 2008); their physical properties are summarized in Table 1 .

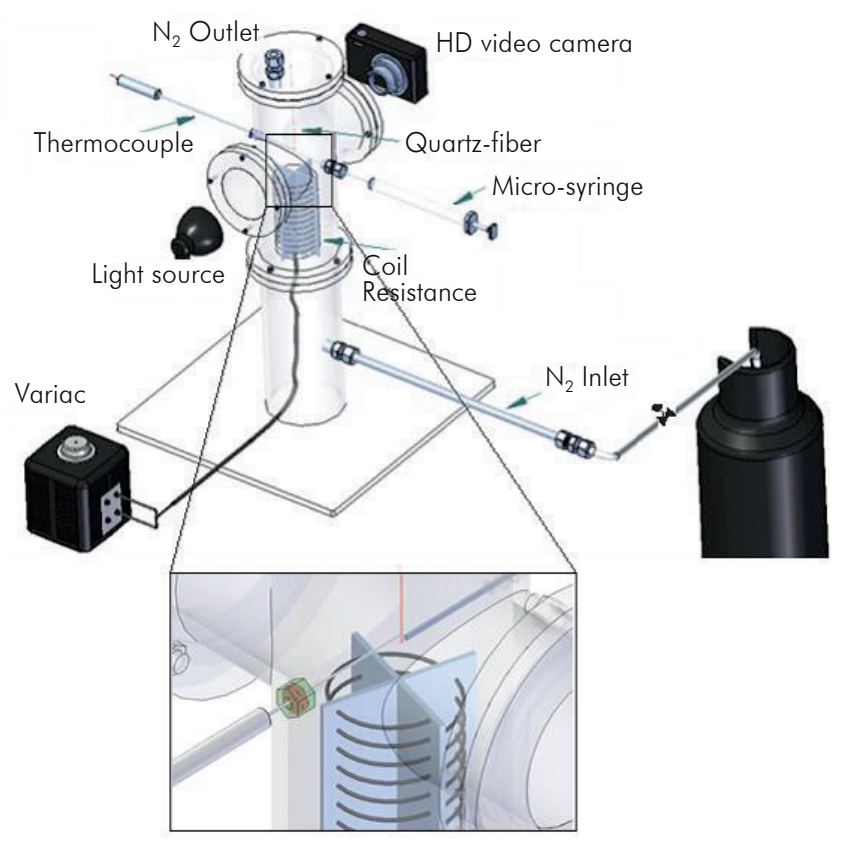

Figure 1. Experimental set-up for droplet evaporation 


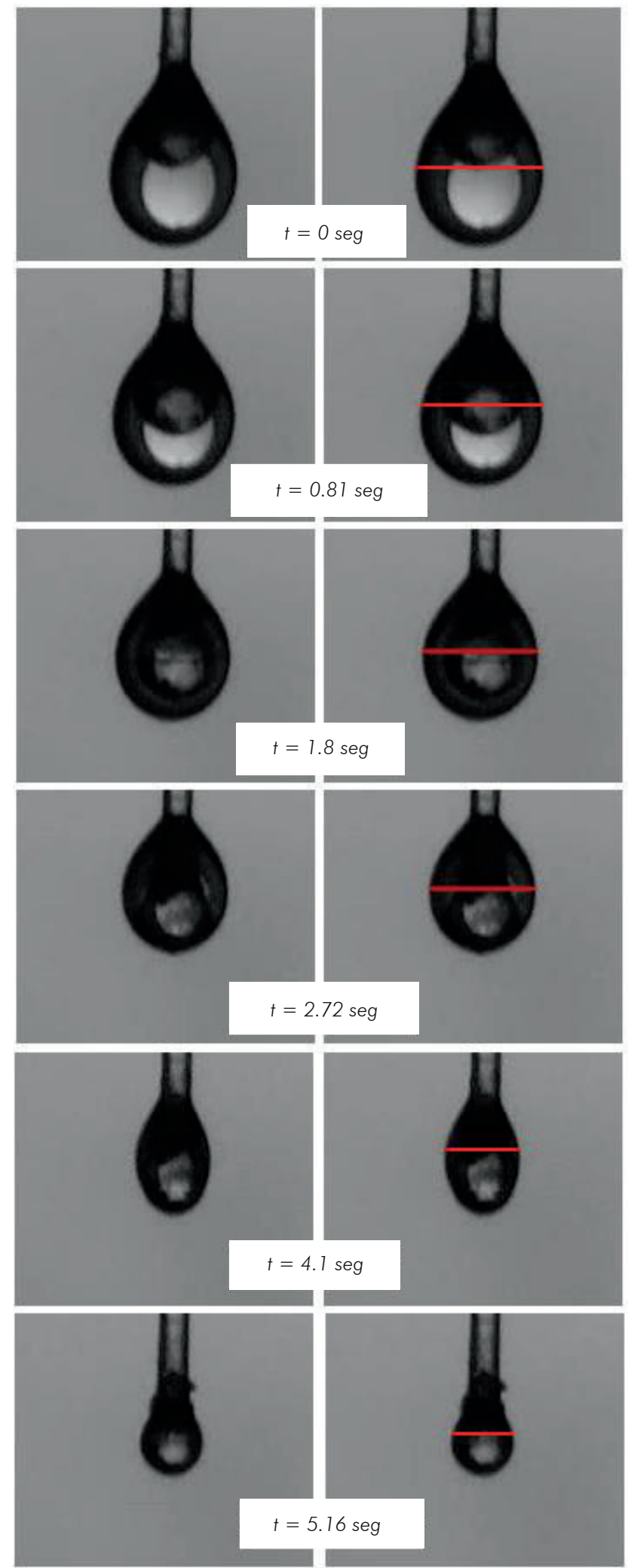

Figure 2. Droplet shrinkage sequence for $n$-heptane evaporation at $553 \mathrm{~K}$ and initial diameter of $1.3 \mathrm{~mm}$

\section{Simulation}

The prediction of droplet lifetimes in evaporation process was performed as shown for Botero and Molina (2010). In summary, the $\mathrm{D}^{2}$ law is used as a standard classical droplet evaporation theory to calculate the evaporation rate at each temperature condition. The droplet is assumed to be at the boiling point (transient heating is not accounted for in this investigation) and an energy balance is performed at the droplet surface with the resulting droplet diameter dependence with time as follows (mathematical expressions and symbols are explained in the nomenclature table at the end of this paper):

$$
\frac{d D^{2}}{d t}=-\frac{8 k_{g}}{p c_{p g}} \ln (B+1) \text { with } \quad \mathrm{B}=\frac{c_{p g}\left(T_{\infty}-T_{b}\right)}{h_{f g}}
$$

This model requires the knowledge of some thermo-physical properties of fuel, such as the thermal conductivity $\left(\mathrm{k}_{\mathrm{g}}, \mathrm{W} / \mathrm{m}-\mathrm{K}\right)$ and heat capacity $\left(\mathrm{C}_{\mathrm{pg}}, \mathrm{J} /\right.$ mol-K) of the fuel vapor, enthalpy of vaporization $\left(\mathrm{h}_{\mathrm{fg}}, \mathrm{J} /\right.$ $\mathrm{kg}$ ) and density $\left(\rho_{\mathrm{f}}\right.$, is the density $\left.\mathrm{kg} / \mathrm{m}^{3}\right)$ of the liquid fuel at boiling point. These properties were calculated based upon the biofuel's chemical composition and structure. A full description of the methodology can be found in Botero \& Molina, (2010). Joback's group-contribution method (Reid et al. 2001) was used to predict the critical properties of each methyl ester using as reference values those presented in Table 1. From these values and some mixing rules (Lee Kesler equation) (Reid et al. 2001), adequate correlations were used to estimate the physical properties of the fuel mixture.

The experimental data of droplet diameter history for n-heptane found in Nomura et al., (1996) was used to assess the experimental set-up and methodology.

\section{RESULTS AND DISCUSSION}

Figure 2, presents the shrinkage of a $1.3 \mathrm{~mm}$ diameter droplet of $n$-heptane during evaporation. The column on the right shows with a red line the place where the diameter-finding routine determined the particle diameter. As time goes on, the droplet diameter decreases. The n-heptane droplet evaporation was simulated and results were compared to experimental results of droplets with two ranges of initial diameters: between $0.6 \mathrm{~mm}$ and $0.8 \mathrm{~mm}$ (Nomura et al. 1996) and between $1 \mathrm{~mm}$ and $1.3 \mathrm{~mm}$ (present work). The evaporation was carried out under a Nitrogen atmosphere at atmospheric pressure at temperatures varying from $390 \mathrm{~K}$ to $555 \mathrm{~K}$. 
Table 1. Palm and Castor Oil biodiesel properties and composition.

\begin{tabular}{|c|c|c|c|}
\hline Properties & Palm Oil biodiesel & Castor Oil biodiesel & Method \\
\hline Density at $150 \mathrm{C}(\mathrm{kg} / \mathrm{m} 3)$ & 873.672 & 926.047 & ASTM D1298 \\
\hline High Heating Value (MJ/kg) & 39.86 & 37.49 & ASTM D240 \\
\hline Cloud Point (K) & 291 & 276 & ASTM D2500 \\
\hline Viscosity at $400 \mathrm{C}(\mathrm{mm} 2 / \mathrm{s})$ & 4.582 & 9.363 & \\
\hline Initial Boiling Point (K) & 576.6 & 571.6 & ASTM D86 \\
\hline Final Boiling Point (K) & 618 & 633.6 & ASTM D86 \\
\hline Cetane Number & $50-57.3$ & 36.28 & ASTM D4737 \\
\hline Fatty Acid Methyl Esters & & & Gas Chromatography \\
\hline Lauric (C 14:2) & 0.305 & 0 & \\
\hline Myristic (C14:0) & 1.027 & 0 & \\
\hline Palmitic (C16:0) & 43.286 & 1.708 & \\
\hline Stearic (C18:0) & 4.249 & 0.969 & \\
\hline Palmitoleic (C16:1) & 0.152 & 0 & \\
\hline Oleic (C18:1) & 41.771 & 3.839 & \\
\hline Linoleic (C18:3) & 9.058 & 5.593 & \\
\hline Linolenic (C18:3) & 0.152 & 2.682 & \\
\hline Ricinoleic (C18:1 OH) & 0 & 85.21 & \\
\hline
\end{tabular}

Figure 3, compares experimental results of n-heptane evaporation with data of Nomura et al. (1996) and with the model predictions at $471 \mathrm{~K}$ and $555 \mathrm{~K}$. Because the initial diameter of the manually-injected droplet changes on each experiment, both diameter and time are normalized, in order to eliminate the differences in the droplet initial diameter. Experimental results obtained in the present research are in agreement with those of Nomura et al. (1996) with slope deviations below $6 \%$. However, the data obtained from the literature seem to present a longer initial heating period. It must be noted that our droplet insertion period ( 2 to 3 seconds) is much longer than that of Nomura et al. (1996) (about $0.6 \mathrm{~s}$ ). Given that the time for full evaporation varies between 5 to 9 seconds (depending on the temperature), our insertion periods are significant and it can be expected that our droplets are preheated during injection, therefore when recording the droplet diameter history we do not observe a heating period. At the lowest temperature $(471 \mathrm{~K})$ both experimental results present an increase in the slope as time advances, suggesting a change in the evaporation rate at low temperatures. The model underestimates the data in Nomura et al. (1996) and presents a better agreement with the experimental data of this study, with standard deviations in the evaporation rate of $20 \%$ and $14 \%$ respectively. As mentioned in the description of the model, it does not account for droplet heating, hence the differences may be due to the longer heating period in the results from the literature. As expected, for the highest temperature in Figure $3 b$, the evaporation rate is higher and, therefore, the droplet lifetime decreases. The experimental results obtained are of the same order of magnitude and follow the same trend of those found in the literature (Nomura et al., 1996) for n-heptane evaporation, with a standard deviation in the evaporation rate of $5 \%$, and also agree with our previous description of the model Botero \& Molina (2010) with a standard deviation of the evaporation rate below $2 \%$.

The evaporation of POB and COB droplets at 0.1 $\mathrm{MPa}$ with an initial droplet diameter in the range of $0.9 \mathrm{~mm}$ to $1.3 \mathrm{~mm}$ was studied. Because of equipment limitations, the range of temperatures used was narrow: for POB $633 \mathrm{~K}$ to $693 \mathrm{~K}$ and for COB $663 \mathrm{~K}$ to 718 $\mathrm{K}$. Due to the limitation of the droplet injection time, for POB the maximum temperature studied was lower because of the fuel evaporated inside the syringe before injection. 
Figure 4 and Figure 5, show the comparison between experimental and numerical results of $(\mathrm{D} / \mathrm{Do})^{2} \mathrm{vs} . \mathrm{t} / \mathrm{Do}^{2}$ for $\mathrm{POB}$ and $\mathrm{COB}$, respectively. Numerical results are shifted to avoid the droplet transient heating period, which is not included in the model. Numerical results are in good agreement with experimental results within experimental error (denoted by the error bars in the figures). Relative standard deviations are within $2-10 \%$ in most of the experiments. However, there is a clear tendency of increasing the deviation in the measurements as the droplet shrinks. This is caused by the diameter mapping algorithm, because for very small droplets a small variation in the number of pixels detected has a stronger effect in the relative droplet size when comparing different repetitions. The effect is also more pronounced between biodiesel and n-heptane, with relative deviations as high as $23 \%$. This may be due to the multicomponent nature of biodiesel that makes it more difficult to evaporate each droplet at the exact same rates. For the lowest temperatures both fuels exhibit a heating period as expected for fuels with high boiling point. Transient heating is only observed at the lowest temperature. Although fuels with high boiling point as those studied in this investigation would exhibit a larger heating period, it is worth noticing that the injection time was about 2 to 3 seconds, time in which fuel heating was taking place. At $663 \mathrm{~K}$ the simulated evaporation rate was shifted by 2 seconds.

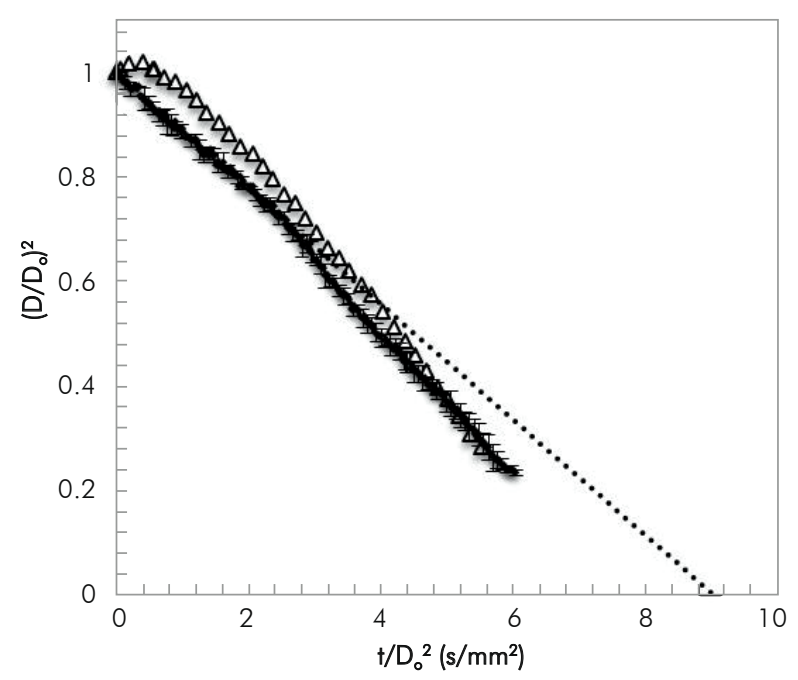

(a)
The only fuel-dependant properties in the model are the thermal conductivity and heat capacity of the fuel vapour and the density and latent heat of vaporization of the fuel. In previous studies Botero \& Molina (2010) it was noted that for this type of fuels the effect of thermal conductivity and heat capacity was minor as both fuels exhibit similar values, whereas the density and latent heat of vaporization played an important role.

With changes in the composition and, therefore, in the mixture properties, the model can reproduce the difference in evaporation rate. The behaviour is consistent with theoretical expectations: as temperature increases droplet lifetimes decrease, which illustrates the importance of the rate of heat transfer to the drop in the evaporation rate.

Results presented in Figure 4 and Figure 5 allow the comparison of evaporation rates of biodiesel fuels at two different temperatures ( $663 \mathrm{~K}$ and $698 \mathrm{~K}$ ). While at $663 \mathrm{~K}$ the evaporation rate of $\mathrm{POB}$ is $0.1275 \mathrm{~mm}^{2} / \mathrm{s}$ and COB is $0.0663 \mathrm{~mm}^{2} / \mathrm{s}$, at $698 \mathrm{~K}$ it is $0.2533 \mathrm{~mm}^{2} / \mathrm{s}$ and $0.1302 \mathrm{~mm}^{2} / \mathrm{s}$ for POB and COB respectively. In general $\mathrm{POB}$ shows a higher evaporation rate compared to COB. This occurs because, for a constant environment temperature, the square diameter evolution in time depends only on fuel properties. In a previous study, we

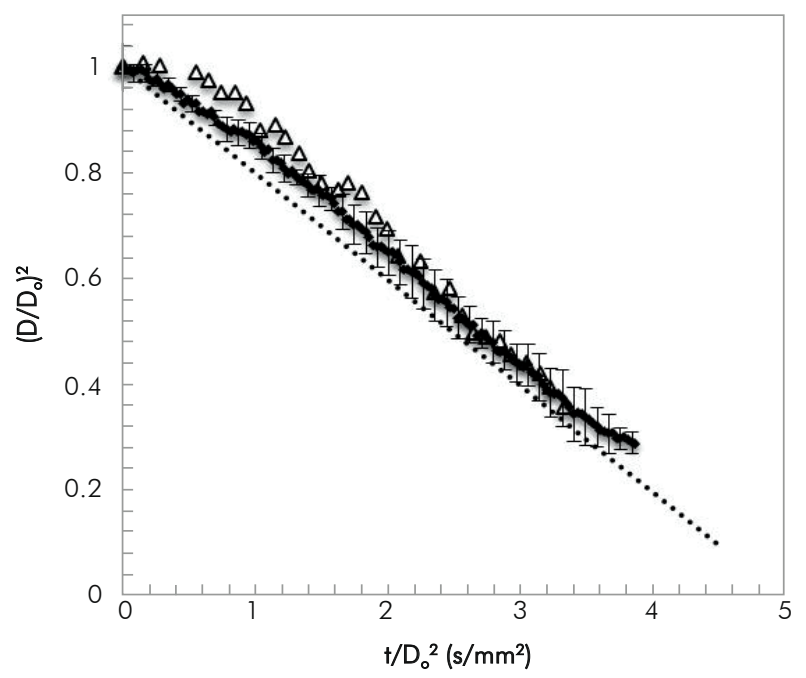

(b)

$$
\text { - Experimental ….... Simulation } \triangle \text { Nomura et al. (1996) }
$$

Figure 3. Variation of squared dimensionless droplet diameter with time divided by squared initial diameter during the evaporation of n-heptane. Comparison of model results with experimental data at $471 \mathrm{~K}(\mathrm{a})$ and $555 \mathrm{~K}(\mathrm{~b})$ 


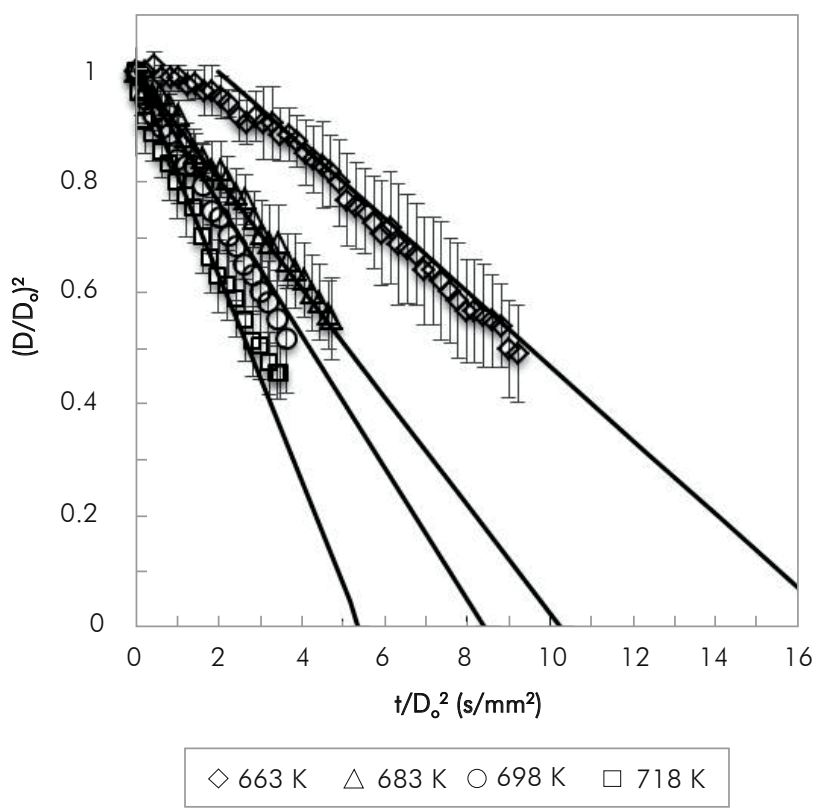

Figure 4. Variation of non-dimensional droplet square diameter with time divided by squared initial diameter for $\mathrm{COB}$, simulation (lines) and experimental (symbols).

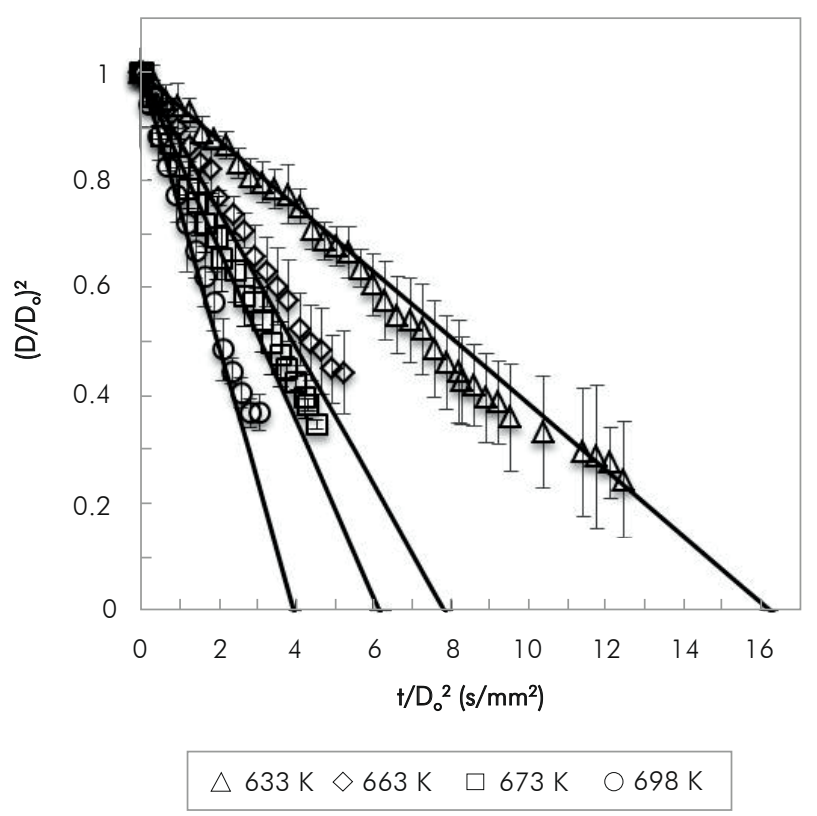

Figure 5. Variation of non-dimensional droplet square diameter with time divided by squared initial diameter for POB, simulation (lines) and experimental (symbols).

estimated the thermo-physical properties of biodiesels and correlated them with the droplet evaporation rate Botero \& Molina (2010). The effect of thermal conductivity and heat capacity was found to be minimal because the two biofuels exhibit similar values in the temperature range of 380-780 K. Instead, the density and latent heat of vaporization were substantially different, where $\mathrm{COB}$ presents higher values than $\mathrm{POB}$.

The effect of a higher unsaturation degree in $\mathrm{COB}$ and the presence of a hydroxyl group in its mayor compound (methyl ricinoleate), were established as the main cause for the higher heat of vaporization and density (Castellan, 1983).

These differences in the thermo-physical properties result in a lower evaporation rate, as validated with the current set of data. In our study case it is observed that stronger intermolecular forces between atoms, as those existent in $\mathrm{COB}$, contribute to a lower evaporation rate.

Even though important processes such as transient heating were not accounted for, the model adequately predicts the evaporation rate of these practical fuels within experimental error. The model enables to elucidate qualitatively the influence of physical properties in the evaporation rate. This is particularly helpful in the case of fuels like biodiesel, which's composition can vary widely depending on its feedstock. The simplicity of the model facilitates the qualitative comparison of the evaporation rate of such fuels only by knowing its composition.

\section{CONCLUSIONS}

- The evaporation rates of droplets of biodiesel fuel from different feedstock were studied. Results of the change of the square droplet diameter with time for $\mathrm{n}$-heptane at $471 \mathrm{~K}$ and $555 \mathrm{~K}$ were in good agreement with experimental data obtained from the literature, and with theoretical expectations, validating the experimental methodology. Due to the manual injection of the droplet, there were longer injection times, hence longer heating periods before the droplet was suspended and stable.

- COB exhibited lower evaporation rates than POB for the temperatures selected, as expected because of its higher level of unsaturation and the presence of hydroxyl groups on the main component: Methyl Ricinoleate. Differences in evaporation rate between $\mathrm{COB}$ and $\mathrm{POB}$ may be important when optimizing the performance of biodiesel engines. 
- $\mathrm{D}^{2}$ law simulation results are in good agreement with experimental data obtained for $\mathrm{POB}, \mathrm{COB}$ and n-heptane for the temperature range evaluated, suggesting the ability of the model to predict the evaporation rates of biodiesel droplets just by having information on the composition and some basic properties.

\section{ACKNOWLEDGEMENTS}

The authors acknowledge the financial support of COLCIENCIAS (Administrative Department of Science, Technology and Innovation of Colombia) under the Research Project 20201007805 and the DIME (Investigation Direction of the National University of Colombia, Campus Medellin under the research Project 20201007095.

\section{REFERENCES}

Allied. (2014). Second Generation Biofuels (Advanced Biofuels) Market. Research Report. Allied Market.

Al Qubeissi, M., Sazhin, S. S., Crua, C., Turner, J. \& Heikal, M. R.. (2015). Modelling of Biodiesel fuel droplet heating and evaporation: Effects of fuel composition. Fuel, 154: 308-318. DOI: 10.1016/j.fuel.2015.03.051.

Basha, S. A., Gopal, K. R. \&Jebaraj, S. (2009). A review on Biodiesel production, combustion, emissions and performance. Renewable and Sust. Energy Rev., 13: 16281634. DOI: 10.1016/j.rser.2008.09.031.

Benjumea, P., Agudelo, J. \& Agudelo, Andres. Basic properties of Palm Oil Biodiesel-diesel blends. Fuel, 87: 10-11. DOI: 10.1016/j.fuel.2007.11.004.

Botero, M. L., Huang, Y., Zhu, D. L., Molina, A. \& Law, C. K. (2012). Synergistic combustion of droplets of ethanol, diesel and Biodiesel mixtures. Fuel, 94: 342-347. DOI: 10.1016/j.fuel.2011.10.049.

Botero, M. L., and Molina A.. (2010). Simulation of the evaporation of drops from Palm and Castor Oil Biodiesels based on physical properties. Rev. Fac. de Ing. Univ. de Antioquia, 56: 40-48.

Castanet, G., Lavieille, P., Lemoine, F., Lebouché, M., Atthasit, A., Biscos, Y. \& Lavergne, G. (2002). Energetic budget on an evaporating monodisperse droplet stream using combined optical methods: Evaluation of the convective heat transfer, Int. J. Heat and Mass Trans., 45: 5053-5067. DOI 10.1016/S0017-9310(02)00204-1.

Castellan, G. W. (1983). Physical Chemistry. 85-90. Third Edition. USA. Addison-Wesley Publishin Company.

Daho, T., Vaitilingom, G., Sanogo, O., Ouiminga, S. K., Segda, B. G., Valette, J., Higelin P. \& Koulidiati, J. (2012a). Model for predicting evaporation characteristics of vegetable Oils droplets based on their fatty acid composition. Int. J. Heat and Mass Trans., 55: 2864-2871. DOI 10.1016/j. ijheatmasstransfer.2012.01.048.

(2012b). Study of droplet vaporization of various vegetable Oils and blends of domestic fuel Oil-cottonseed Oil under different ambient temperature conditions. Biomass and Bioenergy, 46: 653-663. DOI 10.1016/j. biombioe.2012.06.031.

Demirbas, A. (2007). Importance of Biodiesel as transportation fuel. Energy Policy, 35: 4661-4670. DOI: 10.1016/j. enpol.2007.04.003.

Dirbude, S, Vinayak, E. \& Abhijit, K. (2012). Droplet vaporization modeling of rapeseed and sunflower methyl esters. Fuel, 92: 171-79. DOI 10.1016/j.fuel.2011.07.030.

Elwardany, A. E. \& Sazhin, S. S. (2012). Aquasi-discrete model for droplet heating and evaporation: Application to Diesel and gasoline fuels. Fuel, 97: 685-694. DOI: 10.1016/j. fuel.2012.01.068.

Godsave, G. A. E. (1953). Studies of the combustion of drops in a fuel spray - the burning of single drops of fuel. Symp. (Int.) on Comb., 4: 818-830.

Hallett, W. L. H. \& Beauchamp-Kiss, S. (2010). Evaporation of single droplets of ethanol-fuel Oil mixtures, Fuel, 89: 2496-25504. DOI 10.1016/j.fuel.2010.03.007.

Hashimoto, N, Hiroshi, N, Masato, S, Takahiro, M, Hiroyuki, N. \& Yasushi, O. (2015). Evaporation characteristics of a Palm methyl ester droplet at high ambient temperatures. Fuel, 143: 202-210. DOI: 10.1016/j.fuel.2014.11.057.

Knother, G., Krahl, J., Van Gerpen, J.. (2010). Chapter 6 - Fuel Properties. In: Gerhard Knothe. The Biodiesel Handbook. Second Edition. USA, AOCS Press, 238-246. 
Kristyadi, T., Deprédurand, V., Castanet, G., Lemoine, F., Sazhin, S. S., Elwardany A., Sazhina, E. M. \& Heikal, M. R.. (2010). Fuel, 89: 3995-4001.DOI 10.1016/j. fuel.2010.06.017.

Kryukov, A. P., Levashov, V. Y. \& Sazhin, S. S.. (2004). Evaporation of diesel fuel droplets: kinetic versus hydrodynamic models. Int. J. Heat and Mass Trans., 47: 2541-2549. DOI: 10.1016/j.ijheatmasstransfer.2004.01.004.

Law, C. K.. (2006). Combustion Physics. First Edition. USA. Cambridge University Press.

Maqua, C., Castanet, G., Grisch, F., Lemoine, F., Kristyadi, T. \& Sazhin, S. S. (2008). Monodisperse droplet heating and evaporation: Experimental study and modelling. Int. J. Heat and Mass Trans., 51: 3932-3945. DOI: 10.1016/j. ijheatmasstransfer.2007.12.011.

Maqua, C., Castanet, G. \& Lemoine, F. (2008). Bicomponent droplets evaporation: Temperature measurements and modelling. Fuel, 87: 2932-2942. DOI: 10.1016/j. fuel.2008.04.021.

Murugesan, A., Umarani, C., Subramanian, R. \& N. Nedunchezhian. (2009). Bio-diesel as an alternative fuel for diesel engines - A review. Renewable and Sust. Energy Rev, 13: 653-662. DOI: 10.1016/j.rser.2007.10.007.

Nomura, H., Yasushige U., Hans J. R., Jun'ich S. \& Michikata K. (1996). Experimental study on high-pressure droplet evaporation using microgravity conditions. Symp. (Int.) on Comb., 26: 1267-1273. DOI: 10.1016/S00820784(96)80344-4.

OECD/FAO. (2016). Chapter 3: Commodity snapshots. In: OECD-FAO Agricultural Outlook 2016-2025. Paris. OECD Publishing,. 116-117.

Rakopoulos, C. D., Antonopoulos, K. A., Rakopoulos, D. C., Hountalas D. T. \& Giakoumis E. G.. (2006). Comparative performance and emissions study of a direct injection Diesel engine using blends of Diesel fuel with vegetable Oils or bio-diesels of various origins. Energy Conversion and Management, 47: 3272-3287. DOI: 10.1016/j. enconman.2006.01.006.

Reid RC, Prausnitz JM, Poling BR. ( 2001). The Properties of Gases and Liquids. Fifth Edition, USA. McGraw-Hill.
Sazhin, S. S., Abdelghaffar, W. A., Sazhina, E. M. \& Heikal M. R. (2005). Models for droplet transient heating: Effects on droplet evaporation, ignition, and break-up. Int. J. of Thermal Sci., 44: 610-622. DOI 10.1.1.471.3479.

Sazhin, S. S., Al Qubeissi, M., Nasiri, R., Gun'ko, V. M., Elwardany, A. E., Lemoine, F., Grisch, F. \& Heikal, M. R. (2014). A multi-dimensional quasi-discrete model for the analysis of Diesel fuel droplet heating and evaporation. Fuel, 129: 238-66. DOI: 10.1016/j.fuel.2014.03.028.

Sazhin, S. S., Elwardany, A. E., Sazhina, E. M. \& Heikal, M. R. (2011). A quasi-discrete model for heating and evaporation of complex multicomponent hydrocarbon fuel droplets. Int. J. Heat and Mass Trans., 54: 4325-4332. DOI 10.1016/j. ijheatmasstransfer.2011.05.012.

Sazhin, S. S., Kristyadi, T., Abdelghaffar, W. A. \& Heikal, M. R. (2006). Models for fuel droplet heating and evaporation: Comparative analysis. Fuel, 85: 1613-30. DOI: 10.1016/j. fuel.2006.02.012.

Sazhin, S. S., Krutitskii, P. A., Abdelghaffar, W. A., Sazhina, E. M., Mikhalovsky, S. V., Meikle, S. T. \& Heikal, M. R. (2004). Transient heating of diesel fuel droplets. Int. J. Heat and Mass Trans., 47: 3327-3340. DOI: 10.1016/j. ijheatmasstransfer.2004.01.011.

Sirignano, W. A. (1983). Fuel droplet vaporization and spray combustion theory. Prog. Energy and Comb. Sci., 9: 291322. DOI: 10.1016/0360-1285(83)90011-4.

\section{AUTHORS}

\section{Maria Luisa Botero Vega}

Affiliation: Facultad de Minas, Universidad Nacional de Colombia, Sede Medellin, Colombia.

e-mail: mpebvml@nus.edu.sg

\section{Alejandro Molina}

Affiliation: Facultad de Minas, Universidad Nacional de Colombia, Sede Medellín, Colombia.

e-mail: amolinao@unal.edu.co 


\begin{tabular}{|ll|}
\hline & \multicolumn{1}{c|}{ NOMENCLATURE } \\
$D$ & droplet diameter $[\mathrm{m}]$ \\
$t$ & time $[\mathrm{s}]$ \\
$k_{g}$ & thermal conductivity of the fuel vapor $[\mathrm{W} / \mathrm{m}-\mathrm{K}]$ \\
$c_{p g}$ & heat capacity of the fuel vapor $[\mathrm{J} / \mathrm{mol}-\mathrm{K}]$ \\
$h_{f g}$ & enthalpy of vaporization of fuel vapor $[\mathrm{J} / \mathrm{kg}]$ \\
$p_{f}$ & density of fuel vapour $\left[\mathrm{kg} / \mathrm{m}^{3}\right]$ \\
$T_{\infty}$ & temperature of the inert atmosphere $[\mathrm{K}]$ \\
$T_{b}$ & boiling point of the fuel $[\mathrm{K}]$
\end{tabular}


